\title{
Measuring Corporate Social Responsibility Performance for Employees with an NH Approach Method
}

\author{
Nor Hadi \\ IAIN Kudus \\ Eka Mariana \\ Faculty of Economics, Unwahas
}

Abstract

This article explains the empirical research results of the social responsibility performance measurement model for employees that is done by companies by using the NH Approach method. Social responsibility needs to be measured to see the effectiveness of the social responsibility done by a company, as well as to provide legitimacy for stakeholders regarding the company's volunteer efforts in carrying out its responsibilities. The NH Approach is an integrated social responsibility measurement model that was developed based on the legitimacy theory and the stakeholder theory. An evaluation is conducted from two sides, from the stakeholder side as the recipient of social responsibility assistance, and the company management side as the social responsibility assistance provider.

The study used a research and development approach, where the respondents numbered 98 individuals with a response rate level of 92\% (90 respondents who returned the questionnaires). From the 90 questionnaires submitted, only 62 of them were considered complete and analyzed.

The research results reveal that the practice of social responsibility that was done by the company has a grade of Unsatisfactory (C), because the social responsibility index has a 
score of 62.39. Several factors act as the triggers,

Keywords:

social responsibility,

NH Approach,

employee,

legitimization including misunderstandings between parties in understanding social responsibility, underdeveloped social responsibility programs that have already been conducted, and limited social responsibility practice, so that the programs implemented cover various elements of social responsibility.

\section{INTRODUCTION}

A company's existence has two sides of responsibility, as a blade where one side has to be sharp for shareholders, and the other side also has to be sharp for stakeholders. This means that if a company wants to survive, it should consider shareholder importance as well as stakeholder importance, whether internal or external. Both of these stakeholders influence the company and are influenced by the company.

In this kind of a condition, a company must shift its pattern of responsibility, not only be responsible to shareholders (shareholder orientation), as what has been done until now, but must also be accountable towards stakeholders (stakeholder orientation) (Michalak, Macuda, \& Krasaodomska, 2016; Adams \& Frost, 2004). The way that can be taken is by reinforcing and expanding company awareness to engage in social responsibility, both for society and employees (Wheeler \& Elkington, 2001).

In the last decade, social responsibility done by a company is not just as an obligation, but it has become a responsibility for internal and external stakeholders (Hadi, 2017; Hamzah, 2016; Warr, 2007). This condition cannot be separated from society's demands towards negative externalities that arise from company operations. It is also due to the increasing advancements of societal knowledge and awareness about sustainable development. Employees also demand equal portions of company social responsibility. They consider that company awareness is connected with involvement, so that they have more rights in company achievements (Abdullah, Fuong, \& Abdullah, 2010; Joshi \& Gao, 2009).

In actuality, the practice of social responsibility towards employees is not a new concept for companies. Many companies have already included social responsibility activities as an inseparable part of company strategies. Companies have already implemented mandatory 
social responsibility in many dimensions for employees. This is because there is a legal framework that must be observed by companies, including workforce regulations, SPSI, and other such rules on one side. On another side, companies have an interest to empower employees to become a competitive advantage center (Wibisono \& Yusuf, 2007). Social responsibility is a raw material for employee legitimacy and can become an intangible asset.

Nevertheless, there are still many problems that have not been solved in the field. Alternative problems arise on the surface without an end. Some real cases include labor unions, tripartite, industrial relations, wages below the regional minimum standards, employment termination demos, employment protections, health insurance, retirement insurance, racial issues, workforce exploitation, discrimination, and a series of other problems surface alternatively. Meanwhile, on another side, a company may feel that it has already fulfilled its responsibilities towards employees based on the effective regulations (Cormier, Gordon, \& Magnan, 2006; Kazmin \& Kynge, 2001).

Related to the ineffective social responsibility and what is demonstrated by the large number of demanding questions, Hadi (2017) found that the industrial relations problem is triggered by the following factors: first, misunderstandings between the company and employees related with their rights and responsibilities; Secondly, there are no performance measurements that become parameters of effectiveness and social responsibility performance; Thirtly, there is a lack of understanding between the two parties related with the limitations of social responsibility for employees; and Fourtly, social responsibility practice information related with employees.

Especially related to the problem of measuring social responsibility in the employee field, there are not many solutions from academics or practitioners in formulating comprehensive measurement models. The current measurement models are mostly partial and tend to fulfill obligations from the effective regulations.

The NH Approach is a measurement instrument that can be used to measure social responsibility performance. The NH Approach is used to measure social responsibility performance in various fields in a more specific manner. In its measurement, it is not only limited from the company side but also from the stakeholder side. From the 
output obtained various aspects can be known, such as the satisfaction level, the claims, and the level of social responsibility that has been implemented by a company can reduce or eliminate the negative effects of company operations (Hadi, 2017).

The social performance measurement concept that was developed by the NH Approach refers to the legitimacy rules and the stakeholder theory. The measurement that was developed refers to the logic that a company's existence is interrelated with the roles of internal stakeholders and external stakeholders (community, suppliers, legislators, creditors, the environment, bankers, actuaries, directors, shareholders, employees, the market force, and others) (Rowbottom \& Lymer, 2009). They are parties which directly and indirectly influence the company and are influenced by the company (O'Donivan, 2002). Therefore, a company must treat them all equally, in order that the legitimacy gap can be emphasized (Moneva \& Ortas, 2010).

The way to view social responsibility from the NH Approach is from the level of success with the social responsibility practice that is expressed in four dimensions, which are: legal, economic, ethnic, and discretionary, as listed in the key success factors for social performance measurement. This is according to the viewpoint of Caroll (1979), in that a company's existence in the middle of a social environment fosters four responsibilities that must be done, including: legal responsibility, economic responsibility, ethnical responsibility, and discretionary responsibility.

Based on the explanation above, the research question that was developed is: What is the level of social responsibility performance towards employees if measured with the NH Approach?

\section{LITERATURE REVIEW}

\section{Legitimacy Theory}

Legitimacy is a situation and condition where two parties mutually reflect partiality and appreciation, so that a legitimate situation is formed. Legitimacy occurs when the evaluation system of an entity is built with the evaluation system in society (Harsanti, 2011). Deegan (in Hadi , 2017) stated that company legitimacy is the implication direction of company responsibility orientation that is emphasized more on stakeholders. 
The legitimacy theory explains that a legitimate condition occurs when a person's psychological condition and the group are very sensitive towards the surrounding environment, whether physical or nonphysical (Ramanathan, 2001; Harsanti, 2011). Legitimacy must become a company's operational reference, in order that what is produced by a company can be accepted by society (Memed, 2001). A company strives to ensure that its operations are within the framework and norms of society, and tries to make sure that its activities are accepted by society as being "legitimate" (Yovani \& Sekar, 2015; Kolk, 2003).

O'Donovan (2002) and Rowbottom and Lymer (2009) stated that legitimacy is shown from something that is given by society to a company and something that is desired by a company from society's congruence. If this happens, legitimacy is an advantage or potential resource for a company to maintain its concern. Legitimacy is obtained whenever there is congruence, as well as a company's existence is not disturbed or is in line with the existing value system in society and the environment. When there is a shift to become unaligned, then a company's legitimacy can become threatened (Hadi , 2017).

\section{Figure 1:}

Legitimacy Gap Area

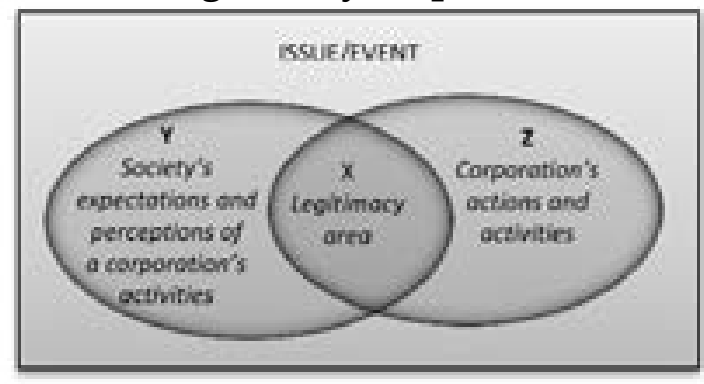

Source: O'Donovan (2002)

O'Donovan (2002) and Lint (2009) provided an illustration of the position of the legitimacy theory as in Figure 1, where $\mathrm{X}$ region is the congruence region between the corporate activities and society's expectations, including congruence with social values and norms. Meanwhile, $\mathrm{Y}$ region and $\mathrm{Z}$ region are incongruent regions between a corporation's actions with the community's expectations. The legitimacy gap can be reduced by expanding $\mathrm{X}$ region through social responsibility practices (O'Donovan, 2002). 


\section{"NH Approach" Based on the Social Responsibility Performance Measurement Concept}

In the last decade, social responsibility has become a new icon in company management. The repercussions of social responsibility are a new magnet to build a company's image in stakeholders' eyes. Within it, there are a series of alignment activities done to society and the environment.

The World Business Council for Sustainable Development (WBCSD) defines CSR or company social responsibility as "a continuing commitment by a business to behave ethically and contribute to economic development while improving the quality of life of the workforce and their families as well as of the local community and society at large. Social responsibility is a company's global commitment to continuously act ethically, operate legally, and contribute to economic improvements, along with improving the employees' and their families' lives, while at the same time improving the quality of the local community and society at large (Wibisono, in Hadi, 2017).

Meanwhile, according to the Global World Bank, "It is the commitment of a business to contribute to sustainable economic development working with employees and their representatives, the local community, and society at large to improve the quality of life in ways that are both good for business and good for development." Social responsibility is a company's commitment to contribute to sustainable development, work in coordination with employees and their representatives, and help local society to improve the quality of life (Budi, 2018).

A company develops along with its increasing awareness to engage in social responsibility. It is a company's strategy and orientation with various kinds of participation. The demands become stronger when society's level of awareness and knowledge increases, so that it opens a new pattern of thinking for society, in that sustainable development must be maintained in the condition where exponentially there is already planet degradation resulting from industrialization.

Despite a company doing social responsibility with various forms of social cost, it does not solve all the problems. Social and environmental problems surface alternatively, even internally. Employee prosperity becomes a new commodity, as well as becomes a specter in company 
management. There are the cases of Lapindo, Nike, Miwon, Bojong trash disposal, radiation, the appearance of deadly viruses, air pollution, global warming, salary increase demands, employment termination, welfare, health, health insurance, discrimination, job safety, minority group attention, and still many other social and environmental problems (Wibisono \& Yusuf, 2007).

Hadi (2007) believe that the effectiveness of social responsibility is often an anomaly because it does not occur with the same perceptions of the parties of interest. Misperceptions happen due to various factors, including: (1) a lack of mutual understanding between society and a company about the limitations of social responsibility; (2) not spreading information about the transformation of social responsibility at large (openness) to society; and (3) social responsibility performance parameters that are not yet standard and integrative, so that their achievements become deviations. Therefore, each group has different interpretations, which causes easy misperceptions. A mechanism is needed that has understanding, communication, and social responsibility measurements that are integrated and standard.

The NH Approach is a social responsibility performance measurement that was constructed by taking the framework of the legitimacy theory and the stakeholder theory. Overall, the NH Approach uses logical thinking, in that a company's existence is inseparable from the roles of internal stakeholders and external stakeholders (community, suppliers, legislators, creditors, environment, bankers, actuaries, directors, shareholders, employees, the market force, and others). Therefore, a company must maintain its alignment with stakeholders, such as through the practice of social responsibility (Hadi, 2017).

Especially for social responsibility for employees, the $\mathrm{NH}$ Approach provides a thinking framework about how to measure their performance. According to the NH Approach, the social responsibility by employee performance was built by using the legitimacy theory basic framework. The core of the social responsibility performance measurement is the level of the legitimacy gap that surfaces. The legitimacy gap is obtained from the incongruence between societal expectations (here employees) with company expectations towards the accepted reality (Hadi, 2017; Moneva \& Ortas, 2010).

Stakeholders (in this case employees) expect that the presence 
of the company (combined with the company employees) will provide advantages like: welfare, salaries, overtime, bonuses, skill improvement and further study assistance, job fields, fair treatment, and other kinds of benefits. If there are unmet expectations, then it will result in employee claims of illegitimacy. It is the same case the other way around. A company is established to meet certain needs (here shareholder orientation) by providing wealth for the owner(s). Therefore, a company wants stakeholder (employee) legitimacy, in the form of employee commitment, employee performance, organizational atmosphere, as well as other employee alignments to the organization. Here lies the importance of legitimacy to support a company to survive.

Figure 2:

Employee Social Performance Measurement Derivation

Diagram Based on the NH Approach

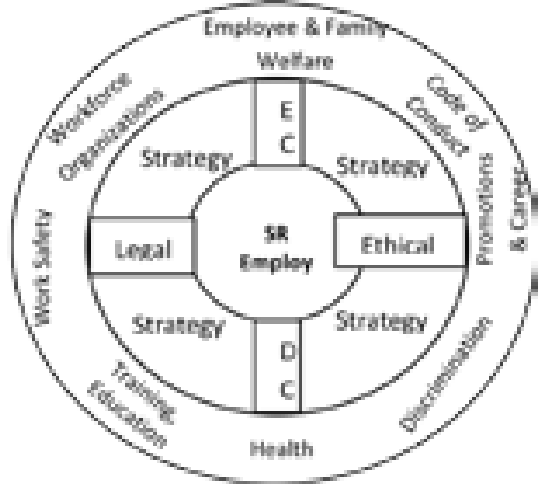

(Source: Hadi, 2017)

Figure 2 depicts a derivation of the $\mathrm{NH}$ Approach social performance dimension that can become a foothold in developing an effectiveness measurement instrument in carrying out social responsibility. This figure is a social responsibility philosophy for employees. The middle part is the social responsibility area for employees that is a social responsibility practice movement followed by its dimensions. Social responsibility for employees is symbolized with the social responsibility bars, which are economic (EC), legal and regulatory, ethical, and discretionary (DC). To conduct the responsibility domain, various relevant strategies are made to show various activities and more effective social responsibility programs. The various social responsibility for employee programs are broken down into various social responsibility performance indicators and dimensions like: (1) 
employee welfare and employee family welfare; (2) health insurance; (3) work safety assurances; (4) promotions and career; (5) training and education; (6) discriminative behavior; (7) workforce organizations; and (8) code of conduct for employees.

\section{RESEARCH METHODOLOGY}

This type of research used a descriptive quantitative approach. Descriptive research strives to describe a symptom, incident, or occurrence that happens now. Then it is analyzed numerically to obtain the social responsibility performance level.

Primary data were used in this research, which were the respondents' opinions related to the social responsibility practices that were accepted by the company employees. The data were taken from surveys and interviews. The surveys were done by distributing social responsibility performance measurement instruments, while interviews were conducted with informants (employees) to refine the data that were obtained through the survey.

The data from the research results were analyzed in the following stages: Coding and editing of the survey results and interviews were done, Grouping and quantifying the respondents' answers was conducted and the social responsibility performance was calculated.

The social responsibility for employees was calculated to obtain the weighted averages:

a. Determine the weighted elements

b. Determine the weights

c. Determine the weight with the formula:

Weighted Average Value $=\frac{\text { weight amount }}{\text { alement total }}=\frac{1}{22}=0.045$

d. Determine the social responsibility index value (SR Index) by using the following formula:

SR Index $=\frac{\text { total value per element }}{\text { total } f \text { tlled elements }} \mathrm{X}$ weight value

e. Interpret the social responsibility index value (SR Index), which was a range of 25-100. Then each evaluation result was multiplied by 25 . The formula is:

SR index value $x 25$

The research results above were categorized as follows: 
Table 1:

SR Index Category

\begin{tabular}{|ccccc|}
\hline No & Int. I SR Value & I SR Conversion & SR Quality & SR Performance \\
\hline 1 & $1.00-1.75$ & $25-43.75$ & $\mathrm{D}$ & Poor \\
2 & $1.76-2.50$ & $43.76-62.50$ & $\mathrm{C}$ & Unsatisfactory \\
3 & $2.51-3.25$ & $62.51-81.25$ & $\mathrm{~B}$ & Good \\
4 & $3.26-4.00$ & $81.26-100$ & $\mathrm{~A}$ & Very Good \\
\hline
\end{tabular}

\section{RESULTS AND DISCUSSION}

The data were collected with surveys and interviews of 98 respondents, who were employees of various departments. To guarantee the validity and reliability, a pre-test was carried out before the instrument was used. A brief description about the respondents' answers of the questions in the research instrument is explained as follows:

\section{Table 2:}

\section{Description of Research Data}

No Unit/Section

1. Production

2. General

2. Administration

3. Fabrication

4. Finance

5. Marketing

6. Finishing and QC

7. Factoring

Total

8. HRD and Staff

Overall Total

\section{Questionnaires Questionnaires} Distributed

50

3

2

4

17

14

4

94

4

98
Returned

48

3

2

4

15

14

0

86

4

90
Incomplete Complete 27 21

3

0

4

16

14

0

58

4

62

Source: Processed Primary Data (Survey Results), 2018

Table 2 above reveals that 98 questionnaires were distributed with an instrument return level (response rate) of $92 \%$. Eight respondents did not return the instruments. From all of the questionnaires returned, 29 of them were not completely filled out, so that they could not be analyzed further. Meanwhile, 62 instruments were returned by the respondents and considered complete to be included in the analysis unit.

\section{Employee Social Responsibility Implementation}

In principle, the company carried out social responsibility, even though the scope and patterns still need to be improved. As seen from 
the motive of the company, it implements social responsibility for more of an economic motive to back up the company's image to improve its profitability rather than a social motive. Dilihat dari motif yang melatarbelakangi perusahaan mengimplementasi social responsibility menunjukkan lebih bersifat economic motive, yaitu mem-back up image perusahaan untuk meningkatkan profitabilitas dibanding social motive.

In looking at the approach used by the company to implement social responsibility towards employees, it tends to be more of a system approach instead of a motive approach. Therefore, the social responsibility practice is more directed to fulfill the effective regulations.

The social responsibility items that are practiced by the company are depicted in the following diagram:

\section{Figure 3:}

\section{Social Responsibility Fields Implemented by the Company}

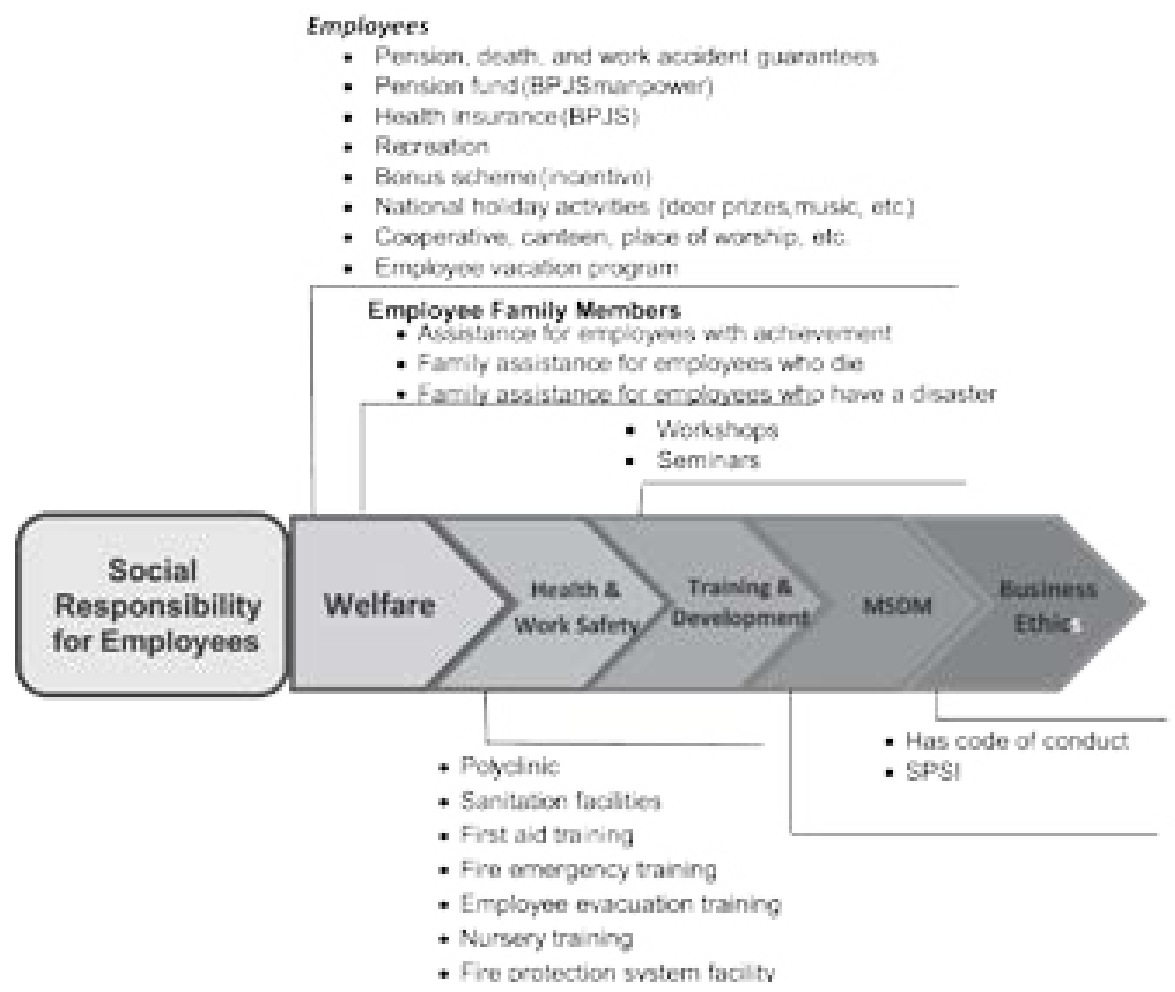

(Source: Processed primary data, 2018)

Figure 3 above is the indicators (forms) of social responsibility that have been conducted by the company towards employees. The kinds of social responsibility activities are carried out by the company 
to assist and align the company with its employees.

The social responsibility for employees is classified into five dimensions: (1) employee welfare; (2) health and job safety; (3) training \& development; (4) human resource management; and (5) business ethics. These dimensions are then broken down into indicators, as depicted in the figure above.

\section{Company Version of Social Responsibility Performance}

In principle, the company has conducted social responsibility as outlined in the effective regulations. The company also realizes the importance of the social responsibility practice.

According to the survey and interview results of the management and company employees, up until now there are no basic problems related with employee claims. The organizational atmosphere runs as normal with a series of regulations, habituations, and the effective code of conduct. In implementing the management policies and regulations, the management does not have any distortions, so that there are no fluctuations or internal protests.

Management admissions related with the practice of social responsibility above are in line with the social responsibility performance measurement results by using the NH Approach. Social responsibility for employees is broken down into 22 indicators. The social responsibility for employees' performance score evaluation calculations reveal a quality grade of "Good".

A more detailed depiction of the social responsibility performance calculation results according to the NH Approach is explained in the following table:

\section{Table 3:}

Social Responsibility Performance Achievements According to the Company Version of the NH Approach

\begin{tabular}{|l|l|c|c|c|c|}
\hline No. & \multicolumn{1}{|c|}{ Program } & $\begin{array}{c}\text { Average } \\
\text { Satisfaction }\end{array}$ & $\begin{array}{c}\text { Average } \\
\text { Expectation }\end{array}$ & Index & Quality \\
\hline 1 & $\begin{array}{l}\text { Adherence to salary } \\
\text { regulations }\end{array}$ & 3 & 3.5 & 75 & $\mathrm{~B}$ \\
\hline 2 & $\begin{array}{l}\text { Insurance program, basic } \\
\text { health coverage, overtime } \\
\text { rewards, health and work } \\
\text { safety guarantees }\end{array}$ & 3 & 4 & 75 & $\mathrm{~B}$ \\
\hline
\end{tabular}




\begin{tabular}{|c|c|c|c|c|c|}
\hline 3 & $\begin{array}{l}\text { Performance bonus } \\
\text { program }\end{array}$ & 2.75 & 3.5 & 68.75 & B \\
\hline 4 & $\begin{array}{l}\text { Employee vacation } \\
\text { program }\end{array}$ & 3,5 & 4 & 87.5 & SB \\
\hline 5 & $\begin{array}{l}\text { Worker organization } \\
\text { effectiveness (like SPSI) }\end{array}$ & 3.25 & 4 & 81.25 & B \\
\hline 6 & $\begin{array}{l}\text { Career development } \\
\text { programs, further study } \\
\text { programs, workshops, and } \\
\text { training programs }\end{array}$ & 2.75 & 3.25 & 68.75 & B \\
\hline 7 & $\begin{array}{l}\text { Education assistance for } \\
\text { employees' family members }\end{array}$ & 1.75 & 2.75 & 43.75 & TB \\
\hline 8 & $\begin{array}{l}\text { Employee family health } \\
\text { assistance program }\end{array}$ & 1.5 & 2.5 & 37.5 & TB \\
\hline 9 & $\begin{array}{l}\text { Health facilities (company } \\
\text { polyclinic, company } \\
\text { doctor, and the like) }\end{array}$ & 3.75 & 4 & 93.75 & SB \\
\hline 10 & $\begin{array}{l}\text { Health facilities (sports } \\
\text { facilities) }\end{array}$ & 2.5 & 3.25 & 62.5 & $\mathrm{~KB}$ \\
\hline 11 & $\begin{array}{l}\text { Exercise training program } \\
\text { for employees }\end{array}$ & 1.5 & 3.25 & 37.5 & TB \\
\hline 12 & $\begin{array}{l}\text { Company code of conduct } \\
\text { (code of ethics) }\end{array}$ & 3 & 4 & 75 & B \\
\hline 13 & $\begin{array}{l}\text { Employee promotion } \\
\text { program }\end{array}$ & 2.25 & 3.75 & 56.25 & $\mathrm{~KB}$ \\
\hline 14 & $\begin{array}{l}\text { Remuneration policy for } \\
\text { employees }\end{array}$ & 1.75 & 2.25 & 43.75 & TB \\
\hline 15 & $\begin{array}{l}\text { Conducive, harmonious, } \\
\text { cooperative, and family- } \\
\text { oriented organization }\end{array}$ & 3.5 & 4 & 87.5 & SB \\
\hline 16 & $\begin{array}{l}\text { Artistic talent development } \\
\text { program for employees }\end{array}$ & 1.5 & 2.25 & 37.5 & TB \\
\hline 17 & $\begin{array}{l}\text { Recreation program for } \\
\text { employees }\end{array}$ & 1.5 & 3.25 & 37.5 & TB \\
\hline 18 & $\begin{array}{l}\text { Gender bias, fairness, and } \\
\text { race policies }\end{array}$ & 2.5 & 3 & 62.5 & $\mathrm{~KB}$ \\
\hline 19 & $\begin{array}{l}\text { Employee recruitment } \\
\text { system that is transparent, } \\
\text { fair, and responsible }\end{array}$ & 3.5 & 4 & 87.5 & SB \\
\hline 20 & $\begin{array}{l}\text { Place of worship facilities, } \\
\text { and assurance of tolerance } \\
\text { between employees }\end{array}$ & 3.5 & 4 & 87.5 & SB \\
\hline 21 & $\begin{array}{l}\text { Awards for employees with } \\
\text { achievements }\end{array}$ & 2.5 & 4 & 62.5 & $\mathrm{~KB}$ \\
\hline
\end{tabular}




\begin{tabular}{|c|l|c|c|c|c|}
\hline 22 & $\begin{array}{l}\text { Housing program for } \\
\text { employees }\end{array}$ & 1.25 & 3.25 & 31.25 & TB \\
\hline & Total Average & 2.54 & 3.39 & 63.63 & B \\
\hline
\end{tabular}

Source: Processed primary data

Social responsibility for employee performance means measuring the company's alignment towards employees as shown by the company's attention and expenditures for welfare, health, safety, career, assistance for employees and their families, and others.

The social responsibility for employee performance score calculation results reveal a "Good" quality category. This is shown from the average score results of all the social responsibility performance measurement indicators that have a value of 63.63 (see Table 3 above).

Meanwhile, the calculation results of each of the social responsibility performance measurement indicators convey there are five indicators that have high scores between 68.7 and 85.7. In addition, there are also five social responsibility for employee performance indicators that have a "Very Good" quality grade, with scores of 87.5 until 93.7 (see Table 3 above). The calculation results reveal that the majority of social responsibility performance measurement indicators are of "Good" quality.

There are five indicators of social responsibility for employee performance that have an "Unsatisfactory" value with scores of 56.25 until 62.5. Also, there are seven indicators that have "Poor" quality for social responsibility for employee performance (see Table 3 above).

If all of the results are accumulated, and the gap is sought between the expectation and reality of social responsibility received by employees, it conveys a "Good" quality value with a score of 63.63.

\section{Employee Version of Social Responsibility (SR) Performance}

Measuring social responsibility performance is not only seen from the company's perspective (see Table 3), but it is also seen from the employees' perspective. This means that evaluating social performance is not only done from the company management side, but it is also considered from what is received and what is felt by employees.

A social responsibility for employee measurement is done to find out employees' opinions or responses related to various programs that have been done by the company, such as whether the social responsibility 
for employee program done by the company provides satisfaction, so that it results in legitimacy or the other way around. The social responsibility for employee performance achievement calculations according to the NH Approach are displayed in the following table:

\section{Table 5:}

Social Responsibility Performance Achievements Based on the Employee Version of the NH Approach

\begin{tabular}{|c|c|c|c|c|c|}
\hline No & Program & $\begin{array}{c}\text { Average } \\
\text { Satisfaction }\end{array}$ & $\begin{array}{c}\text { Average } \\
\text { Expectation }\end{array}$ & Index & Quality \\
\hline 1 & Adherence to salary regulations & 3.18 & 3.60 & 79.74 & $\mathrm{~B}$ \\
\hline 2 & $\begin{array}{l}\text { Insurance program, basic health } \\
\text { coverage, overtime rewards, health } \\
\text { and work safety guarantees }\end{array}$ & 3.06 & 3.51 & 76.72 & $\mathrm{~B}$ \\
\hline 3 & Performance bonus program & 2.41 & 3.56 & 60.34 & KB \\
\hline 4 & Employee vacation program & 2.77 & 3.38 & 69.39 & $\mathrm{~B}$ \\
\hline 5 & $\begin{array}{l}\text { Worker organization effectiveness } \\
\text { (like SPSI) }\end{array}$ & 2.56 & 3.10 & 64.22 & $\mathrm{~B}$ \\
\hline 6 & $\begin{array}{l}\text { Career development programs, } \\
\text { further study programs, workshops, } \\
\text { and training programs }\end{array}$ & 2.31 & 3.26 & 57.76 & KB \\
\hline 7 & $\begin{array}{l}\text { Education assistance for employees' } \\
\text { family members }\end{array}$ & 2.17 & 3.16 & 54.31 & KB \\
\hline 8 & $\begin{array}{l}\text { Employee family health assistance } \\
\text { program }\end{array}$ & 2.86 & 3.34 & 71.55 & B \\
\hline 9 & $\begin{array}{l}\text { Health facilities (company } \\
\text { polyclinic, company doctor, and } \\
\text { the like) }\end{array}$ & 3.12 & 3.48 & 78.02 & $\mathrm{~B}$ \\
\hline 10 & Health facilities (sports facilities) & 1.89 & 3.22 & 47.41 & KB \\
\hline 11 & $\begin{array}{l}\text { Exercise training program for } \\
\text { employees }\end{array}$ & 1.72 & 3.14 & 43.10 & TB \\
\hline 12 & $\begin{array}{l}\text { Company code of conduct (code } \\
\text { of ethics) }\end{array}$ & 2.69 & 3.21 & 67.24 & $\mathrm{~B}$ \\
\hline 13 & Employee promotion program & 2.24 & 3.20 & 56.03 & $\mathrm{~K}$ \\
\hline 14 & Remuneration policy for employees & 2.12 & 2.58 & 53.01 & KB \\
\hline 15 & $\begin{array}{l}\text { Conducive, harmonious, } \\
\text { cooperative, and family-oriented } \\
\text { organization }\end{array}$ & 2.60 & 3.5 & 65.08 & B \\
\hline 16 & $\begin{array}{l}\text { Artistic talent development } \\
\text { program for employees }\end{array}$ & 1.86 & 2.89 & 46.55 & KB \\
\hline 17 & Recreation program for employees & 1.98 & 3.41 & 49.56 & $\mathrm{~KB}$ \\
\hline
\end{tabular}




\begin{tabular}{|l|l|c|c|c|c|}
\hline 18 & $\begin{array}{l}\text { Gender bias, fairness, and race } \\
\text { policies }\end{array}$ & 2.70 & 3.24 & 67.67 & $\mathrm{~B}$ \\
\hline 19 & $\begin{array}{l}\text { Employee recruitment system that } \\
\text { is transparent, fair, and responsible }\end{array}$ & 2.43 & 3.37 & 60.77 & $\mathrm{~KB}$ \\
\hline 20 & $\begin{array}{l}\text { Place of worship facilities, and } \\
\text { assurance of tolerance between } \\
\text { employees }\end{array}$ & 3.17 & 3.63 & 79.31 & $\mathrm{~B}$ \\
\hline 21 & $\begin{array}{l}\text { Awards for employees with } \\
\text { achievements }\end{array}$ & 1.95 & 3.48 & 48.70 & $\mathrm{~KB}$ \\
\hline 22 & Housing program for employees & 1.96 & 3.29 & 49.14 & $\mathrm{~KB}$ \\
\hline & Total Average & $\mathbf{2 . 4 4}$ & $\mathbf{3 . 3 0}$ & $\mathbf{6 1 . 1 6}$ & $\mathrm{KB}$ \\
\hline
\end{tabular}

Source: Processed primary data, 2018

Table 4 above explains about the company social responsibility for employee calculation results, where the evaluators (respondents) are employees. Actually, the employee evaluation is the real social responsibility that is received and felt by the employees.

There were 22 indicators that measured social responsibility for employee performance that were transformed to become question items in the research instrument. The social responsibility performance measurement results revealed that the average score was 61.16 (Unsatisfactory) (see Table 4 above). Thus, it can be said that overall, social responsibility performance based on employee perception is in the "Unsatisfactory" quality category, which is a "C" service quality with a satisfaction index of 61.16 and an average satisfaction of 2.44 .

If seen from each of the indicator scores, there are ten social responsibility for employee performance indicators with a "Good" quality category and a score between 67.24 and 79.74). However, the opposite condition also occurred, where based on the social responsibility for employee performance indicator calculations, there are 11 indicators that have an "Unsatisfactory" quality value with scores between 43.10 and 60.77) (see Table 4 above).

\section{Social Responsibility for Employee Performance with an NH Approach Method}

After calculating the company social performance from the management and employee perspectives, and obtaining the scores or 
ratings for each social performance category, then the integral social performance was determined according to the NH Approach calculation method.

The social performance measurement was determined by looking at the gap between expectation and reality (management version) with the expectation and reality received by employees (employee version). This method was applied by referring to the legitimacy theory thinking framework.

After doing a comparison (gap) between social performance satisfaction and expectation, the company social performance showed a gap average score of 62.39 . The calculation results convey that social responsibility for employee performance has an "Unsatisfactory" (C) quality criterion. To understand this in more detail, it is explained in the following table:

Table 5:

Social Responsibility for Employee Performance Based on the NH Approach Method

\begin{tabular}{|c|l|c|c|c|}
\hline No & Evaluator & Average Satisfaction & Average Expectation & Satisfaction Index \\
\hline 1 & Company & 2.54 & 3.39 & 63.63 \\
\hline 2 & Employee & 2.44 & 3.30 & 61.16 \\
\hline & Average & $\mathbf{2 . 4 9}$ & $\mathbf{3 . 3 2}$ & $\begin{array}{c}\mathbf{6 2 . 3 9} \\
\text { (Unsatisfactory) }\end{array}$ \\
\hline
\end{tabular}

Source: Processed primary data, 2018

Table 5 above displays the NH Approach tabulated results of social responsibility for employee performance. The social responsibility calculation gap score reveals an "Unsatisfactory" quality criterion. This is shown with an SR index of 22 social responsibility performance indicators of 62.39 with an average satisfaction of 2.49 and expectation of 3.32. The element with the highest evaluation from the company was company commitment and health facility. Meanwhile, from the employee perspective, the highest element evaluation was for company seriousness and adherence in paying according to the regency minimum wage. The element which had the lowest score based on company perception was having an employee housing program. Then the element which had the lowest score according to the employee perception was the exercise training and physical exercise program. 


\section{CONCLUSION}

Based on the discussion of the research results above, the following conclusions can be drawn as the social performance measurement results with an NH Approach from the company side have an SR index of 6.63. Meanwhile, the social performance measurement results that were examined from the employee side have an SR index of 6.16. Based on the social responsibility performance gap tabulated results from the company and employee sides, an SR index of 62.39 was obtained. This reveals that social responsibility performance for employees is in the "Unsatisfactory" quality category. The low social responsibility performance index does not mean the company has a low commitment in the practice of social responsibility, but rather it is due to many triggering factors, such as: misunderstandings between the parties in understanding social responsibility, the need for the existing social responsibility to be strengthened, as well as the social responsibility practice needs to be expanded, so that the programs enacted can cover various elements of social responsibility.

Although this research has been conducted as well as possible, there are still various weaknesses and limitations, especially related to the following items: first, the NH Approach measurement dimension needs to be developed. Besides that, the measurement field also has to be adjusted according to the measured context. Second, the research did not do enough internalization of several contextual aspects, so that many qualitative aspects also need to be considered and measured in social responsibility performance achievements.

In order to develop and perfect the study, the following suggestions are provided for future research: first, develop social responsibility dimensions based on the context that will be researched, so that the measured results will be more complete and integrated. Secondly, expand the stakeholders who are involved in evaluating, so that it can reduce evaluator subjectivity. Finally, since social responsibility activities are not documented well by the company management, data retrieval has to be done carefully, so that items which need to be considered and measured are included in the evaluation. 


\section{References}

Adams, C. \& Frost, G. R. (2004). The development of corporate websites and implications for ethical, social, and environmental reporting through these media. Edinburgh, The Institute of Chartered Accountants of Scotland.

Abdullah, H., \& Fuong, C. C. (2010). The implementation of ISO 14001 environmental management system in manufacturing firms in Malaysia. Asian Social Science, 6 (3).

Aerts, W., Cormier, D., Gordon, I. M., \& Magnan, M. (2006). Performance disclosure on the web: An exploration of the impact of managers' perceptions of stakeholder concerns. The International Journal of Digital Accounting Research, 6 (12), 159-194.

Connelly, J. T., \& Limpaphayom, P. (2004). Environmental reporting and firm performance: Evidence from Thailand. The Journal of Corporate Citizenship, 13, 137-149.

Gunawan, Y., \& Mayang Sari, Sektor. (2015). Pengaruh sustainability reporting terhadap nilai perusahaan dengan instrument opportunity sebagai variabel moderating. E-Journal Akuntansi Transaksi 2(1), 1-12.

Hadi, N. (2017). Corporate Social Responsibility, $2^{\text {nd }}$ Ed. Yogyakarta: Graha Ilmu.

Hamzah, A. (2016). Pengungkapan tanggung jawab sosial perusahaan pada sektor keuangan di bursa efek Indonesia. Jurnal Riset Keuangan dan Akuntansi 2 (2), 6-92.

Harsanti, P. (2011). Corporate social responsibility dan teori legitimasi. Mawas, 24 (1), 206-207.

Joshi, P. L., \& Gao, S. S. (2009). Multinational corporate social and environmental disclosures (CSED) on websites. International Journal of Commerce \& Management, 19, 27-44. 
Kazmin, A., \& Kynge, J. (2001). Breathless in Bangkok: Environmental degradation throughout Asia has reached critical levels. Financial Times, June 23, p. 7.

Kolk, A. (2003). Trends in sustainability reporting by the fortune global 250. Business Strategy and the Environment, 12, 279-291.

Kuasirikun, N. (2005). Attitudes to the development and implementation of social and environmental accounting in Thailand. Critical Perspectives on Accounting, 16, 1035-1057.

Kuasirikun, N., \& Sherer, M. (2004). Corporate social accounting disclosure in Thailand. Accounting, Auditing, \& Accountability Journal, 17, 629-660.

Lint, L. W. (2009). Corporate social and environmental disclosure in emerging securities markets. North Carolina Journal of International Law and Commercial Regulation, 35, 1-32.

Micalak. Halina Waniak, Macuda. Malgorzata, \& Krasodomska. Joana. (2016). Corporate social responsibility and accounting in Poland: A literature review. Accounting and Management Information System, 15(2), 255-303.

Moneva, J. M., \& Ortas, E. (2010). Corporate environmental and financial performance: A multivariate approach. Industrial Management \& Data Systems, 110(2), 193-210.

Putu Diva Awatara, Gusti I, Bandani Anwar, (2016). Pengaruh tanggung jawab sosial terhadap komitmen organisasi dan kinerja karyawan. Jurnal Aplikasi Manajemen, 14(2), 3-4.

Ratanajongkol, S., Davey, H., \& Low, M. (2006). Corporate social reporting in Thailand, the news is all good and increasing. Qualitative Research in Accounting \& Management, 3, 67-83.

Rowbottom, N., \& Lymer, A. (2009). Exploring the use of online corporate sustainability information. Accounting Forum, 33(2), 176-186. 
Siregar, B., \& Gautama. (2015). Penerapan CSR dalam pandangan Islam. JURIS, 14(2) (July-December 2015).

Tagesson, T., Blank, V., Broberg, P., \& Collin, S. O. (2009). What explains the extent and content of social and environmental reporting in Swedish listed corporations. Corporate Social Responsibility and Environmental Management, 16, 352-364.

Warr, P. (2007). Long-term economic performance in Thailand. ASEAN Economic Bulletin, 24, 138-163.

Wheeler, D., \& Elkington, J. (2001). The end of the corporate environmental report? or the advent of cybernetic sustainability reporting and communication. Business Strategy and the Environment, 10, 1-14. 